\title{
Magnetic Resonance Imaging a Key Tool in Labeling "Vascular Compression Syndrome": A Case Report
}

\author{
Dessai Teja Deepak ${ }^{1 *}$ and Varsha $\mathbf{M}^{2}$ \\ ${ }^{1}$ Assistant Professor in Audiology, India \\ ${ }^{2}$ Dr. S. R. Chandrasekhar institute of Speech and Hearing, India
}

Submission: November 16, 2018; Published: November 29, 2018

*Corresponding author: Dessai Teja Deepak, Assistant Professor in Audiology, Dr. S. R. handrasekhar institute of Speech and Hearing, Hennur Main Road, Lingarajapuram, Bangalore, India

\section{Abstract}

The anterior inferior cerebellar artery supplies blood to nervous system. Abnormal variations in anterior inferior cerebellar artery can produce profound effects on vestibular and hearing systems. Single case reports have been shown in the literature. Accordingly, we report a case from a mounting community in India. It is deemed to be worthy of documentation.

\section{Introduction}

The anterior inferior cerebellar artery (AICA) is one among the three pairs of arteries supplying blood to cerebellum Izumi [1]. Occlusion of this branch can produce vast clinical features. In the year 1936, McKenzie coined the term "Vascular compression syndrome", which refers to a collection of diseases due to direct contact between a cranial nerve and a blood vessel, Jannetta [2]. This conception has further been extended to explain diseases related to various cranial nerves. The vestibulocochlear nerve function may hinder due to redundant arterial loops, thereby leading to otologic symptoms Jannetta et al. [3]. Even though plentiful research has been carried out in this area, the survival of vascular compression syndromes continues to be questioned.

\section{Need for the Study}

Vascular compression syndrome is reported to source reduction in dysfunctional hyperactivity of vestibulocochlear nerve. This notion of dysfunction is supported by the theory that a vascular loop around AICA is an etiological factor Girard [4]. These lead to the establishment of association between vascular compression syndrome and a number of clinical conditions Markowski [5]. Luiz et al. [6] quoted 33 total tested individuals with vascular loop of AICA, to have incidence of $42.4 \%, 42.4 \%$ and $75.8 \%$ for tinnitus, hearing loss and dizziness respectively. Similarly, the accounted prevalence among Brazilian population is $22 \%, 9 \%$ and $42 \%$ for tinnitus, hearing loss and dizziness respectively and a report of increase in these rates was noted with advancing age (Cruz, et. al., 2009) [7]. However, controversy is uprooted concerning the pathogenesis of this condition and clinical features in Indian population.

Aim of the Study: The study was undertaken to ascertain the clinical otologic profile in individuals with vascular loops.

\section{Case Report}

The present case study is an exploratory clinical design involving a 40 year old housewife, who visited our department for medical help. Complaints of severe pulsating unilateral headache (left/right side) and vertigo lasting for 10-15 hours as the major symptoms since 5 years affecting her quality of life were reported. Further, on detailed case history evaluation, reports of photophobia, phonophobia, blurring of vision, weakness and tingling sensation of upper limbs were noted. Detailed audiological and vestibular evaluation was performed by an experienced Audiologist. In the audiological investigation, hearing thresholds between 250 to $8 \mathrm{~K} \mathrm{~Hz}$ were estimated using Modified Hughson and Westlake procedure Carhart \& Jerger [8] in an acoustically sound treated room. Middle ear status and acoustic stapedial reflex was examined using GSI Tymp-Star Pro. In addition, Speech Audiometry was administered using a standardized ISHA spondee word list 3 in Hindi; PB word list 3 in Hindi (1968-69) test material to obtain speech recognition threshold and speech discrimination scores. Outer hair cell function and contralateral suppression was also assessed using the University of Florida protocol available in I-LOV 6. In addition, ipsilateral and contralateral Auditory Brainstem Response and High Rate-Low Rate test was carried out using Biologic Navigator Pro software. The audiological testing profile was further concluded with m-BIC test using the same software.

Furthermore, vestibular assessment was credited with a detailed case history, followed by subjective vestibular tests such as Rhombergs test Rhomberg [9], Fukuda test Fukuda [10], subjective head shake test Barany [11], subjective head impulse test Halmagyi \& Curthoys [12] and skew deviation test Hertwig [13] to rule out central pathology contributing to the exhibited 


\section{Global Journal of Otolaryngology}

symptoms. This was further accompanied with positional tests like Dix-Hallpike test (Dix and Hallpike, 1952) [14] and Supine head roll test Pagnini et al. [15] to identify the type of BPPV. cVEMP and oVEMP were carried out through Biologic Navigator Pro software to know the status of otoliths in vestibular system. Electronystagmography was considered for the study to confirm on the diagnosis using RMS computer based ENG system.

\section{Results \& Discussion}

Hearing status of the female individual was; right ear with hearing sensitivity within normal limits and left ear with minimal hearing loss. Immittance audiometry revealed bilateral 'A' type tympanogram with absent ipsilateral and contralateral acoustic reflexes. Speech recognition threshold in right ear and left ear were $20 \mathrm{dBHL}$, with good speech discrimination scores of $100 \%$ in both right and left ear. Outer hair cell function test showed bilateral good outer hair cell functioning with good contralateral suppressions. Auditory Brainstem Response and High Rate-Low Rate test showed abnormal study with poor morphology, delay in absolute peak latencies and absence of peak I and peak III. In accordance with the audiological findings, the individuals further m-BIC testing complimented the test findings. The results showed abnormal binaural interaction. A detailed vestibular profile with subjective vestibular evaluation obtained negative results excluding central pathology. In addition, peripheral positional vertigo was ruled out with administration of Dix-Hallpike test and supine head roll test. oVEMP and cVEMP revealed normal findings which was further supported with Electronystagmography. These clinical features and symptoms directed the provisional diagnosis towards vestibular migraine if Magnetic Resonance Imaging (MRI) test reports were normal. Hence the individual was advised to undergo MRI to rule out vestibular migraine.

The second visit of the individual with the MRI test reports to the department caused a red flag towards the urgent need for neurology consultation. The reports stated type III AICA vascular loop on right and type II AICA vascular loop on left side (entering but not extending $>50 \%$ of the length of IAC). Our test findings specify the association between audio-vestibular symptoms and presence of vascular loop in the AICA. These findings are in accordance with the literature data Grocoske [16]. Chronic compression is reported to cause regional nerve demyelination, similarly, reduced vascular perfusion of nerves is caused due to disturbances in the distribution of blood flow. This explains the clinical profiles of vascular compression syndrome. Even though the theory of vascular compression is widely acknowledged for hemifacial spasm and trigeminal neuralgia, its implication and relationship with otologic symptoms such as tinnitus, hearing impairment and dizziness is not yet well understood. This may therefore, leave us unanswered with hearing being preserved in the given individual. Otologic complaints are comparatively common in daily life, and thus, it is not infrequent to see individuals in which the grounds of such complaints are not recognized; for several of these cases, vascular compression has been considered an etiological factor De Ridder et al. $[17,18]$.

\section{Conclusion}

The present study was focused upon highlighting the audio-vestibular status in individual with vascular loop. While performing comprehensive evaluation, we observed a switch in the direction of the possible provisional diagnosis using MRI. This necessitates caution among medical and allied health professionals to deliver customized and timely services aiding in accurate assessment and labeling of the individual through subjective and objective evaluation. The study also contributes on compulsorily performing detailed audiological and vestibular test battery along with brain MRI.

\section{References}

1. Izumi M, Terao S, Sobue G (1996) Clinical features of anterior inferior cerebellar artery territory infarcts - a study of ten patients No to Shinkei 49(2): 152-156.

2. Jannetta PJ (1975) Neurovascular cross-compression in patients with hyperactive dysfunction symptoms of the eighth cranial nerve. Surg Forum 26: 467-469.

3. Jannetta PJ, Mrller MB, Mrller AR (1984) Disabling positional vertigo. N Engl J Med 310: 1700-1705.

4. Girard N, Poncet M, Caces F(1997) Three-dimensional MRI of hemifacial spasm with surgical correlation. Neuroradiology 39(1): 46-51.

5. Markowski J, Gierek T, Kluczewska E (2011) Assessment of vestibulocochlear organ function in patients meeting radiologic criteria of vascular compression syndrome of vestibulocochlear nervediagnosis of disabling positional vertigo. Med Sci Monit 17(3): 169173.

6. Luiz de AJ, Cristina HK, Angela BW (2016) Vascular loops in the anterior inferior cerebellar artery, as identified by magnetic resonance imaging, and their relationship with otologic symptoms. Radiol Bras 49(5): 300-304.

7. Cruz MS, Oliveira LR, Carandina L (2009) Prevalence of self-reported hearing loss and attributed causes: a population-based study. Cad Saúde Pública 25: 1123-1131.

8. Carhart R, Jerger J (1959) Preferred method for clinical determination of pure-tone thresholds. Journal of Speech \& Hearing Disorders 24: $330-345$.

9. Rogers JH (1980) Romberg and his test. J Laryngol Otol 94(12): 14011404.

10. Fukuda T (1959) The stepping test. Acta Otolaryngol 50: 95-108.

11. Bárány R (1907) Untersuchungen über das Verhalten des Vestibularapparates bei Kopftraumen und ihre praktische Bedeutng. Verhandungen der Deutschen otol Gessellschaft 252-256.

12. Halmagyi GM, Curthoys IS (1988) A clinical sign of canal paresis. Arch Neurol 45(7): 737-739.

13. Hertwig H (1985) Experilmenta quaedam de effectibus laesionum in partibus encephali singularibus et de verosimili harum partium functione. Berolini, formis Feisterianis et Eisersdorf 1826. Ind Cat Surg-Gen 6:185.

14. Dix M, Hallpike C (1952) Proceedings of the Royal Medical SocietySection of Otology. 45: 15-28.

15. Pagnini P, Nuti D, Vannucchi P (1989) Benign paroxysmal vertigo of the horizontal canal. Otorhinolaryngology 51: 161-170.

16. Grocoske FLB, Mendes RCCG, Vosguerau R (2011) Achados otoneurológicos em pacientes com diagnóstico de alça vascular de VIII par craniano na ressonância magnética. Arq Int Otorrinolaringol 15(4): 418-425. 
17. De Ridder D, Ryu H, Mrller AR, et al. (2004) Functional anatomy of the human cochlear nerve and its role in microvascular decompressions for tinnitus. Neurosurgery 54(2): 381-388.
18. Makins A, Nikolopoulos T, Ludman C, O Donoghue G (1998) Is there a correlation between vascular loops and unilateral auditory symptoms? Laryngoscope 108(11): 1739-1742.

\section{Your next submission with Juniper Publishers will reach you the below assets}

- Quality Editorial service

- Swift Peer Review

- Reprints availability

- E-prints Service

- Manuscript Podcast for convenient understanding

- Global attainment for your research

- Manuscript accessibility in different formats

( Pdf, E-pub, Full Text, Audio)

- Unceasing customer service

Track the below URL for one-step submission https://juniperpublishers.com/online-submission.php 